\title{
EDITORIAL
}

\section{In This Issue: Doctor-Patient, Doctor-System, Doctor-Public}

\author{
Jobn J. Frey III, MD, Associate Editor \\ Ann Fam Med 2008;6:194-195. DOI: 10.1370/afm.846
}

$\mathrm{T}$ his issue of the Annals contains a number of articles that look inside the doctor-patient relationship from the patient's, as well as the physician's, point of view.

\section{DOCTORS AND PATIENTS}

One of my teachers once reminded me to always take into account the power of countertransference. The article by Street and colleagues ${ }^{1}$ uses a sophisticated process to come to the conclusion that patients prefer doctors with whom they share values. In groups, patients gravitate toward different physicians by their perception of what physicians think and believe. Where there is concordance, there is increased trust and a higher likelihood for agreement on management of problems. Conversely, in communities, particularly rural ones, with less choice of physicians with whom patients can match values, earning trust may be more challenging. Fortunately, by using patient-centered behaviors, clinicians can increase the chance that shared values can be achieved.

Both doctors and patients hold shared decision making as an important value. Krones and colleagues ${ }^{2}$ show, through a randomized prospective trial of concentrated education of doctors about shared decision making, that patients are more satisfied with the process and doctors feel better about the decisions which are reached. Alas, actual behaviors that reduce risk are more resistant to change.

The article by Goodyear et al reinforces the general observation that pictures are more powerful than words, or at least more effective at conveying important information about risk. ${ }^{3}$ One conclusion from this study might be that physicians should be taught the effective selection and use of the graphic representation of data, particularly in the era of electronic health records. Very few medical schools or residencies include such training. Those interested in learning the power of visual representation might want to look at the work of Tufte, ${ }^{4,5}$ which is used by scientists worldwide. Spiegelhalter's editorial on the subject ${ }^{6}$ elegantly highlights one of the essential elements of primary care practice-living with uncertainty-and explains, with a pack of cards and a coin toss, why there is uncertainty both for doctors and patients. Our attempt to help things be clearer inevitably bumps up against the fundamental truth of clinical care: there is no answer, only a series of choices that change with time, information, and human unpredictability.

Katoaka and colleagues describe the often benign nature of pulmonary crackles in many older patients. ${ }^{7}$ Their work suggests a natural history for clinical findings. Not everything that changes as we age indicates disease. I put this article to good use last month when a patient of mine, an 82-year-old man, still had his persistent crackles at both bases. In an interesting role reversal, I reassured the cardiologist that there were data to show that the patient's rales were a natural process.

\section{DOCTORS, SYSTEMS, AND THE PUBLIC}

The carrot-and-stick element of the widely used payfor-performance to "incentivize" doctors to adhere to guidelines seems to work in the study by Campell and colleagues from the United Kingdom. ${ }^{8}$ Goals are met, and increased reimbursement for doing so is a result. Another consequence, however, seems to be that a guideline-driven process of care leaves physicians feeling that they are becoming less skilled, are losing their sense of place in the clinical enterprise, and are less connected with patients. The result might be wealthier doctors with less emotional investment in their practices and, if satisfaction for both doctors and patients comes from the relationship, lower overall satisfaction.

Physicians are aware of the evils of antibiotic overuse, but we are slower to change than one would predict, given the high visibility of cautionary literature in both the general and medical press. Stille and colleagues $^{9}$ report that a multimethod intervention to 
reduce inappropriate prescribing through physician education, as well as public information, did reduce prescribing of antibiotics, but the campaign did not affect physician self-reported attitudes or practices in the intervention group compared with a control group. Physicians sometimes exemplify the bumper sticker that says, "I have my mind made up. Don't confuse me with the facts."

Devoe's essay on the unsustainability of our current health system invokes the need for individual responsibility to do something beyond provide good care. ${ }^{10}$ We not only have to warn others of the impending end of medicine-as-we-know-it but also must work with our colleagues and communities to do something about it.

\section{OTHER ARTICLES OF INTEREST}

Two articles in this issue address methods and tools of primary care research and practice. Hahn and colleagues ${ }^{11}$ report that medical record flow sheets are associated with adherence to guidelines for diabetes assessment and treatment, but not with achievement of intermediate outcome targets. Fisher and colleagues ${ }^{12}$ introduce a new tool for measuring emotional distress and concerns in patients with diabetes.

A meta-analysis finds that, although nonergot dopamine agonists reduce the severity of symptoms of restless leg syndrome, significant numbers of patients discontinue their use because of adverse events, ${ }_{1}^{13}$ perhaps an example of the treatment being worse than the disease?

Finally, Middleton's essay ${ }^{14}$ reflects on the pain of those left behind after a physician suicide and calls for greater attention to the issue of physicians' mental health.

Please share your thoughts about these articles in the online discussion at http://www.AnnFamMed.org.

\section{REFERENCES}

1. Street RL, O'Malley KJ, Haidet P, Cooper LA. Understanding concordance in patient-physician relationships: personal and ethnic dimensions of shared identity. Ann Fam Med. 2008;6(3):198-205.

2. Krones $\mathrm{T}$, Keller $\mathrm{H}$, Sadowski $\mathrm{E}$, et al. Absolute cardiovascular disease risk and shared decision making in primary care: a randomized controlled trial. Ann Fam Med. 2008;6(3):218-227.

3. Goodyear-Smith F, Arroll B, Chan L, Jackson R, Wells S, Kenealy T. Patients prefer pictures to numbers to express cardiovascular benefit from treatment. Ann Fam Med. 2008;6(3):213-217.

4. Tufte E. The Visual Display of Quantitative Information. 2nd ed. Cheshire, CT: Graphics Press; 2001.

5. Tufte E. Envisioning Information. Cheshire, CT: Graphics Press; 1990.

6. Spiegelhalter DJ. Understanding uncertainty. Ann Fam Med. 2008;6(3):196-197.

7. Kataoka H, Matsuno O. Age-related pulmonary crackles (rales) in asymptomatic cardiovascular patients. Ann Fam Med. 2008; 6(3):239-245.

8. Campbell SM, McDonald R, Lester $H$. The experience of pay for performance in English family practice: a qualitative study. Ann Fam Med. 2008;6(3):228-234.

9. Stille CJ, Rifas-Shiman S, Kleinman K, Kotch J, Finkelstein J. Physician responses to a community-level trial promoting judicious antibiotic use. Ann Fam Med. 2008;6(3):206-212.

10. DeVoe JE. The unsustainable US health care system: a blueprint for change. Ann Fam Med. 2008;6(3):263-266.

11. Hahn KA, Ferrante JM, Crosson JC, Hudson SV, Crabtree BF. Diabetes flow sheet use associated with guideline adherence. Ann Fam Med. 2008;6(3):235-238.

12. Fisher L, Glasgow RE, Mullen JT, Skaff MM, Polonsky WH. Development of a brief diabetes distress screening instrument. Ann Fam Med. 2008;6(3):246-252.

13. Baker WL, White CM, Coleman Cl. Effect of nonergot dopamine agonists on symptoms of restless legs syndrome. Ann Fam Med. 2008;6(3):253-262.

14. Middleton JL. Today I'm grieving a physician suicide. Ann Fam Med. 2008;6(3):267-269. 